\title{
Plagiarism in articles published in journals indexed in the Scientific Periodicals Electronic Library (SPELL): a comparative analysis between 2013 and 2018
}

\author{
Marcelo Krokosczid
}

Correspondence: marcelok@fecap.br Fundação Escola de Comércio Álvares Penteado/FECAP, Av. Liberdade, 532, São Paulo, SP 01502-001, Brazil

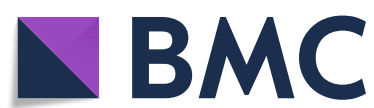

\section{Introduction}

It has been reported in the literature that studies marred by a lack of scientific integrity due to scientific misconduct such as plagiarism or redundant publication (self-plagiarism) and works containing gift or ghost authorship are a recurring problem, which has intensified as of late (Amos 2014; Associação Nacional de Pesquisa e Pós-Graduação e Pesquisa em Administração (ANPAD) 2017; Committee On Publication Ethics (COPE)

(c) The Author(s). 2021 Open Access This article is licensed under a Creative Commons Attribution 4.0 International License, which permits use, sharing, adaptation, distribution and reproduction in any medium or format, as long as you give appropriate credit to the original author(s) and the source, provide a link to the Creative Commons licence, and indicate if changes were made. The images or other third party material in this article are included in the article's Creative Commons licence, unless indicated otherwise in a credit line to the material. If material is not included in the article's Creative Commons licence and your intended use is not permitted by statutory regulation or exceeds the permitted use, you will need to obtain permission directly from the copyright holder. To view a copy of this licence, visit http://creativecommons.org/licenses/by/4.0/. The Creative Commons Public Domain Dedication waiver (http://creativecommons.org/publicdomain/zero/1.0/) applies to the data made available in this article, unless otherwise stated in a credit line to the data. 
2011; Conselho Nacional de Desenvolvimento Científico e Tecnológico (CNPq) 2011; Council of Science Editors (CSE) 2018; Fundação de Amparo à Pesquisa do Estado de São Paulo (FAPESP) 2011; Koocher and Keith-Spiegel 2010; Van Nordeen 2011).

In January, 2011, the Coordenação de Aperfeiçoamento de Pessoal de Nível Superior (Coordination for the Improvement of Higher Education Graduates - CAPES) ${ }^{1}$ recommended that all Brazilian institutions of higher education create "policies of awareness and information concerning intellectual property, adopting specific procedures seeking to limit the practice of plagiarism in the preparation of theses, monographs, articles and other texts on the part of students and other members of their communities" (Coordenação de Aperfeiçoamento de Pessoal de Nível Superior 2011). In the same year, the main of research support agencies in Brazil presented policies aimed at restraining the occurrence of fraud and misconduct in scientific publications, citing the fabrication or invention of data, the falsification of results, and authorship fraud (plagiarism) among the types of fraud and misconduct (Conselho Nacional de Desenvolvimento Científico Tecnológico 2011; Fundação de Amparo à Pesquisa do Estado de São Paulo 2011).

These measures were aligned with those which institutions of higher education around the world were practicing and were in conformity with the codes of research integrity of international organizations, such as the following: the U.S. Department of Health and Human Services (2005), the Australian government (2007), and the Research Councils UK (2017). International entities, including CSE beginning in 1957 and COPE since 1997, have given support to science editors with the goal of creating and implementing a culture of ethics and good practices in scientific research activities.

In Brazil, the Associação Nacional de Pesquisa e Pós-Graduação e Pesquisa em Administração - ANPAD (National Association of Research and Graduate Studies and Research in Administration) had its manual "Boas Práticas da Publicação Científica: um manual para autores, revisores, editores e integrantes de corpos editoriais" (Good Practices in Scientific Publishing: a manual for authors, reviewers, editors and members of editorial committees) approved during the II Fórum de Editores Científicos de Administração e Contabilidade (II Forum of Scientific Editors in Administration and Accounting), held in 2010. In addition, in 2011, the Associação Brasileira dos Editores Científicos - ABEC (Brazilian Association of Scientific Editors - ABEC) held the Encontro Nacional de Editores Científicos (National Meeting of Scientific Editors), with the theme "Integrity and Ethics in Scientific Publishing". Among its objectives, the association sought "to develop and refine the publication of technical-scientific periodicals and refine the communication and dissemination of information". In February 2015, ABEC signed an agreement with iThenticate ${ }^{\circ}$, a software for detecting plagiarism in articles submitted to periodicals for publication, enabling the employment of this tool by its members. In 2017, ABEC, in partnership with CSE, published the "Diretrizes do CSE para Promover Integridade em Publicações em Periódicos Científicos" (Policies of the CSE for Promoting Integrity in Scientific Journals) in Portuguese.

\footnotetext{
1"CAPES is a public institution, linked to the Ministry of Education, responsible for graduate education in Brazil (Master and $\mathrm{PhD}$ courses). Its role includes evaluation of such courses, access and communication of scientific production, investment on preparation of high level human resources (as professors and researchers) and promotion of international and scientific information." (Coordenação de Aperfeiçoamento de Pessoal de Nível Superior 2009).
} 
All these organizations agree that misconduct in scientific research manifests itself fundamentally via three practices condemned by researchers: fabricating research data; falsifying results; and authorship fraud, that is, the undue appropriation of another author's content without the due attribution of credit. Furthermore, condemnable practices such as redundancy in publications (self-plagiarism) are considered in the same category as the sloppy handling of research subjects or piracy.

Focusing more closely on the object of this study, plagiarism can be defined as "signing or otherwise presenting oneself as the author of an artistic or scholarly work belonging to another person. To imitate someone else's work" (Ferreira 1986, p. 249). According to Brazil's law concerning the rights of an author (Law, 9610/98), the practice, which is considered forgery, is characterized as the unauthorized reproduction of a work, meriting the penalties outlined in Article 184 of the Penal Code. However, in the Brazilian academic environment, the problem is understood to be academic misconduct or dishonest intellectual practice, which can manifest itself through self-plagiarism or the purchase of academic works produced by others. These modalities of the occurrence of plagiarism are extrapolated from the juridical notion related to plagiarism by not including the characteristic of using someone else's work in an incorrect manner. Self-plagiarism, for instance, is not addressed by the law because it is a situation in which authors themselves reuse their own works; i.e., there is no offense in relation to others' rights. Therefore, it falls beyond legal issues and is essentially considered essentially an ethical problem since a redundant publication (self-plagiarism) "disrupts scientific publishing by over-emphasizing results, increasing journal publication costs, and artificially inflating journal impact, among other consequences" (Eaton and Crossman 2018).

Table 1 presents the most common types of plagiarism in the international academic context according to the literature and the practices in some teaching institutions. It is interesting that types 1 and 3 describe some forms of plagiarism that can be considered misappropriation a legislative standpoint. However, types 4 and 7 are kinds of plagiarism that do not harm authorship rights but are considered scientific misconduct and, consequently, ethically unacceptable practices.

Despite the increasing interest in academic plagiarism on the part of institutions involved in teaching and research, the subject can still be considered to have arisen relatively recent in Brazil, and little original work on the topic has been produced; however, it is currently being increasingly studied in the academic community (Demo 2011; Krokoscz 2011; 2012a, b). For example, in a search for the keywords "plagiarism" and "plagio" in the SPELL platform, among 48 thousand documents, only two publications on the topic were found: Veludo-de-Oliveira et al. (2014) and Costa et al. (2017). Nevertheless, beyond these, through other platforms, Brazilian discussions related to business plagiarism can also be found in Andrade (2011), Barbastefano and Souza (2007), Barros and Duque (2015); Fachini and Domingues (2008), Innarelli (2011), Valente et al. (2010), Neumann (2018), Silva and Domingues (2008), and Tomazelli (2011).

In summary, although these studies contribute to deepening the subject, have been only incipient discussions over the last 8 years. Nevertheless, in an article published in the Revista da Associação dos Docentes da USP (Journal of the Association of Professors of the University of São Paulo), researchers Luiz Henrique Lopes dos Santos and Erney Plessmann de Camargo, faculty members at the University of São Paulo University (USP), recognized that the concerns regarding plagiarism are becoming increasingly 
Table 1 Types and descriptions of plagiarism

\begin{tabular}{|c|c|c|}
\hline Types of Plagiarism & $\begin{array}{l}\text { Adaptation in } \\
\text { Portuguese }\end{array}$ & Description \\
\hline 1 Word for Word Plagiarism & Plágio direto & $\begin{array}{l}\text { Verbatim copy of an original text without the use of } \\
\text { quotation marks or margin indentation to indicate a } \\
\text { quotation or the identification of the source by means } \\
\text { of a reference. }\end{array}$ \\
\hline 2 Paraphrasing Plagiarism & Plágio Indireto & $\begin{array}{l}\text { Reproduction of the ideas of an original source using } \\
\text { different words, but without identifying the original's } \\
\text { location. }\end{array}$ \\
\hline 3 Mosaic Plagiarism & Plágio Mosaico & $\begin{array}{l}\text { Unidentified reproduction of fragments of different } \\
\text { sources that are mixed with words, conjunctions, } \\
\text { and prepositions so that the text makes sense. }\end{array}$ \\
\hline 4 Collusion Plagiarism & Plágio Consentido & $\begin{array}{l}\text { Presentation of works as being one's own that were } \\
\text { in fact authored by others (friends, colleagues, or } \\
\text { relatives, among others) or purchased. }\end{array}$ \\
\hline 5 Apt Phrase Plagiarism & Plágio de Chavão & $\begin{array}{l}\text { Reproduction of expressions, truisms or phrases } \\
\text { provoking the effect elaborated by other authors. }\end{array}$ \\
\hline 6 Plagiarism of Secondary Sources & Plágio de Fontes & $\begin{array}{l}\text { Reproduction of bibliographic references encountered } \\
\text { in other sources that were never consulted directly by } \\
\text { the citing author. }\end{array}$ \\
\hline 7 Self-plagiarism & Autoplágio & $\begin{array}{l}\text { Reproduction of one's own works previously presented } \\
\text { in other circumstances without identifying this fact to } \\
\text { obtain one or more advantages, such as being cited } \\
\text { in the work of others. }\end{array}$ \\
\hline
\end{tabular}

Sources: Badge and Scott 2009; Concordia University 2019; Garcia 2013; Georgetown University (2019); Harris 2001; Loui 2002; Martin 1994; Massachusetts Institute of Technology 2018; Roig 2015; Stanford University 2019; Starovoytova 2017; University of Cambridge 2019a; b; Universiteit Ghent 2019; The University of Hong Kong 2019; University of Cape Town 2019; University of Pretoria 2019; and University of Oxford 2019

important and that knowledge about the subject is scant. Luiz Menna-Barreto, another researcher that was interviewed, considered that the climate concerning "productivism" (measurable professorial productivity), which has characterized the academic scenario in recent years, could be a factor related to this (Biondi 2011). In addition, an article published in Nature showed that, among researchers, plagiarism was third among the practices of academic dishonesty in the judgment of peer reviewers (Koocher and Keith-Spiegel 2010). Indeed, the problem has attained international importance and has been verified as one of the reasons for the increase in retracted articles (Van Nordeen 2011 , p. 27). This study revealed that cases of retractions occurring among the articles published in the Web of Science, as well as in PubMed, 44\% correspond to problems of scientific misconduct, including plagiarism and self-plagiarism; and the other $56 \%$ were problems associated with research errors and nonreproducible results, among other problems. Carver et al. (2011) also emphasize that plagiarism has significantly contributed to the increase in the number of retractions; and for Masic (2014, p. 145), "the biggest reason for retractions in the last thirty years is plagiarism and self-plagiarism."

According to the website Retraction Watch, launched in 2010 with the aim of monitoring the indices of the occurrence and motives of the retraction of scientific articles in publications, in the field of life sciences, in 2013, there were 203 retractions related to plagiarism involving text, image, data or articles. In 2018, the database of the website catalogued 182 retractions for the same reasons (Retraction Watch 2019).

\footnotetext{
"Plágio" is the term in Portuguese that corresponds to "plagiarism" in English. Since the platform contains articles principally in Portuguese and some others also in English, the search was done in both languages using the two key words.
} 
Another study found further evidence of the occurrence of plagiarism in scientific publications in the field of biomedicine found in PubMed for the period from 2008 to 2012. The study found that $35 \%$ of the retractions could be attributed to plagiarism or self-plagiarism in the sample studied. In addition, the study identified the 20 countries with the greatest numbers of works retracted as a result of plagiarism and selfplagiarism. Brazil was included among them, with $44,4 \%$ of the articles by its authors being retracted due to the same motives (Amos 2014).

Although the proportion, in percentages, of works retracted is low, it must be remembered that there is no standard minimum acceptable index for such practices in the academic world.

In addition, it is still unclear whether the numbers of retractions that have been verified are related to an increase in the frequency of plagiarism-related practices in recent years or result from increasing the identification of such instances because of the rigor in editing and whistle-blowing processes, internet visibility and the use of technological resources such as software that detects textual similarities.

Considering this scenario, the main objective of this study was to analyze the possible occurrence of plagiarism and self-plagiarism in a nonrandom sample of articles published in learned journals in the field of administration indexed in the Scientific Periodicals Electronic Library (SPELL) information database, a repository of scholarly studies that offers free access to technical and scientific information in the area of business (www.spell.org.br). In addition, the study sought to compare the results obtained with those reported in a similar study in 2013 and to analyze the guidelines that each of the journals composing the sample provided to authors regarding plagiarism.

The study is justified as a consequence of the increasing attention given to the problem of plagiarism by important Brazilian institutions concerned with research, such as the Coordination for the Improvement of Higher Education Graduates (CAPES), the National Council of Scientific and Technological Development (CNPq) and the Foundation for the Support to Research of the State of São Paulo (FAPESP), requiring that this issue be addressed.

The positions held by these institutions regarding the need to disseminate guidelines and take action to address plagiarism and other types of scientific misconduct was first put forth in 2011 when CAPES issued a document containing recommendations for all public and private universities in Brazil to adopt procedures to address academic plagiarism (Coordenação de Aperfeiçoamento de Pessoal de Nível Superior 2011). It is important to note that the initiative taken by CAPES occurred due to a request by the Brazilian Bar Association (OAB) in the state of Ceará that recommended, inter alia, that all institutions of higher education in Brazil should "use software to search for similarity in the Internet $[\ldots]$, adopt policies of awareness and information about intellectual property, aiming at suppressing plagiarism in the academic community" (OAB 2010). ${ }^{3}$ Since then, some measures have been implemented to address plagiarism. For instance, since 2013, FAPESP, one of the major public agencies financing research in the state of São Paulo, has kept a "shame page" on its institutional website on which it publishes a list of researchers and projects having revealed scientific misconduct (Fundação de

${ }^{3}$ Free translation of the following passage: "utilizem softwares de busca de similaridade na internet [...] adotem políticas de conscientização e informação sobre a propriedade intelectual, visando coibir o plágio na comunidade acadêmica" (OAB 2010). 
Amparo à Pesquisa do Estado de São Paulo 2014). In 2017, FAPESP started to refuse projects from research institutions that did not have an office of academic integrity (Alves 2017).

In addition, despite repercussions from reports of recent cases of plagiarism by Brazilian researchers uncovered in learned journals in the national media, the reduced number of studies conducted and submitted for publication by Brazilian authors has been concentrated on higher education. However, it is known that some of the major obstacles related to the rejection of scholarly articles submitted for publication are the problems of a methodological nature or may be related to a lack of theoretical depth or difficulties in referencing (i.e., the correct identification of the sources consulted), among other issues (Job et al. 2009).

Nevertheless, it is important to learn which measures related to the verification and prevention of plagiarism have been adopted by scientific journal editors in relation to the articles submitted for publication. Likewise, there are no diagnostic evaluations that can provide evidence of the extent to which the submissions of researchers do or do not possess plagiarized sections. Obviously, the scope of this study excludes "exposing" authors or learned journals. It seeks to contribute to the identification and discussion of the question insufficiently addressed in the Brazilian scientific literature. Consequently, it is hoped that the findings of this investigation will contribute to improving the procedures for elaborating and submitting research reports for publication.

\section{Methodology}

The articles analyzed in the study were obtained from the SPELL database, a repository of scholarly articles in the field of business. The main reason to choose this database for the analysis is its free access to full-text technical and scientific information.

In 2013, using the bibliographic search for published articles cited in the SPELL database, 546 articles published in 47 different journals were identified. After 5 years, a new survey of articles published from 08/2013 to 08/2018 was performed. In this period, 121 journals were identified, and three of them were disregarded because they were no longer published (Desafio: Revista de Economia e Administração (published until 2010 and then continued as Desafio Online) (ISSN 1678-1821); RAC-Eletrônica (ISSN 1981-5700), published until January 2009; and Revista de Estudos de Administração Rea (ISSN 1518-3645), published until December 2009), resulting in the identification of 28,259 published articles.

A random sample corresponding to one article from each journal in both periods was selected. This was done by means of attributing an identification number (ID) to each article in the database. The ID of the first article and that of the last one published were verified, and a number was drawn using the website www.random.org. After the number was drawn, the selected article was downloaded and input to the plagiarism detection software iThenticate $e^{\bullet}$. All the articles selected and input to the plagiarism detector were then classified in a control spreadsheet, consisting of the following information: the Qualis/Capes identifier, article title, DOI or permanent link, authors, and publication date.

The articles drawn were input to iThenticate ${ }^{\bullet}$ software in the two phases of the research. The software operates by creating a search for similarities between the submitted text and texts that have been published on the internet, including in publications 
with restricted access, such as in the case of publishers (Elsevier, Springer, Nature, Taylor \& Francis, and Wiley-Blackwell), indexers, and databases (EBSCOHost; Emerald Journals; Proquest; Pub-Med/Medline, and Cengage Learning), among other scholarly journals, and its own software database, thus consolidating a repertory for comparison with some 142 million documents (IThenticate ${ }^{\circ} 2019$ ).

\section{Findings and discussion}

Initially, the analysis was conducted using the policies and instructions for authors and/ or submission manuals provided by the journals to authors interested in submitting their work for publication. The intention was to verify the existence or lack of guidelines related to plagiarism or self-plagiarism in publications seeking to clarify these issues for authors beforehand. This guidance is part of the flowchart concerning what to do in cases of the suspicion of plagiarism and redundancy in scholarly manuscripts that can be found in the document elaborated by the Committee On Publication Ethics (COPE) and that is aimed at editors of scholarly journals. The text notes that "the instructions to authors should include a definition of plagiarism and state the journal's policy on it" (Committee On Publication Ethics 2016; 2018).

In the analysis conducted in 2013 in which data were analyzed but not published, it was found that only one journal (2\%) among the 47 analyzed journals mentioned the word "plagiarism" in its policies, although the majority of the directives required guarantees on the part of authors that no type of violation of authors' rights were contained in the submitted work. However, we also observed that one of the publications studied cited a directive related to redundancy (self-plagiarism) in its submission guidelines, although it utilized a different term to refer to the subject: overlapping of publication (Ebape 2014).

According to Eaton and Crossman (2018), self-plagiarism is a sub-category of plagiarism and is considered to be complex and polemical. The study and debate of selfplagiarism have received growing interest from editors with the objective to establish clear and specific guidelines about the issue to authors during the process of submitting scientific work in social science areas. One of the topics that has demanded attention is defining the percentage of a previously written text that an author can reuse, considering that some parts of the work, such as the description of the methods, do not usually vary substantially, which justifies their reproduction. Several authors have considered that up to $30 \%$ of a previous text could be reused, but this does not serve as a fixed rule since it depends on the area of study and the guidelines of each periodical (Bird and Sivilotti 2008; Roig 2015; Samuelson 1994).

Usually, the publication of two articles with considerable overlap is not acceptable, even if they are published in different academic periodicals. Various publications that have a unique data collection should only be permitted under the following guidelines: (a) if it is impossible to write a single article within the maximum number of 30 pages, and (b) if the articles present distinct approaches and purposes. The editor should be advised of a submission when the article has, in some form, already been published online.

Periodicals were also found that established directives in relation to the originality of the work, whether in Brazil or abroad, clarifying that they considered work that had been presented in preliminary versions in scholarly events acceptable for publication. 
Some journals encouraged and authorized authors to publish and disseminate their work in online vehicles such as institutional repositories or on personal pages, considering that this could have a positive effect on the visibility and increased probability of the work being cited. For example, "Authors have permission and are encouraged to publish and disseminate their work online (e.g. in institutional repositories or on their own personal pages) at any time before or during the editorial process, since this could generate productive alterations, as well as increase the impact and the citing of the published work [ ...]" (Revista de Gestão, Finanças e Contabilidade 2014).

In relation to what was learned about plagiarism and self-plagiarism in the analyses conducted in 2013, it was determined that there was word-for-word plagiarism (copying verbatim from a source without any acknowledgement) in 31 published articles (65.9\%), and no relevant similarities with other publications were encountered in 16 articles (34.1\%).

Table 2 presents the list of the periodicals analyzed with the numbers of articles that were published by the time the similarity analysis was conducted. In this stage of the investigation, we only identified whether there were instances of plagiarism and selfplagiarism.

The column "Qualis" refers to a scale established by the Brazilian Ministry of Education that is used to classify the level of qualification of periodicals that publish scientific work in postgraduate programs in Brazil. During the time of this study, the evaluation strata adopted by this program varied from the highest quality, A1, to A2, B1, B2, B3, B4, B5, and C (zero). (BRASIL 2016). As can be seen in the data in Table 2, it is possible to notice that there are occurrences of plagiarism/self-plagiarism in both more qualified (A2) and less qualified periodicals (B5).

The types of plagiarism mostly found were those copying the sentences of a source or paragraphs of other sources verbatim without the use of quotation marks or indenting the text and lacking any indication of the original document or source. Furthermore, we discovered cases of self-plagiarism (redundancy), that is, works by the same author that had already been published in other periodicals or event annals.

The present work did not analyze the extension of occurrences of self-plagiarism. The observations conducted identified the following: the copy of entire articles the same authors had previously presented in scientific events and published in conference proceedings, and parts of texts published in other studies and reused without proper citation.

The software did not allow us to identify the occurrence of indirect plagiarism (paraphrasing; i.e., when the original source is rewritten but no source is credited through an indirect quote (indication of authorship within the text), and no reference given to the source in the form of detailed identification at the end of the work. The use of a reference to the source and quoting the author are two essential conditions for avoiding the inappropriate use of a reproduced source.

In the 2018 analyses, the website of each of the 118 journals selected for this research and indexed in the database was visited. Initially, we identified the existence of directions or guidelines related to ethics or good research practices on the principal page. Then, a second step was searching for information connected to these topics in the section "about the journal." In these sections, we searched for "plágio or plagiarism." If this 
Table 2 Journals indexed in the SPEL $L$ from January to June 2013

\begin{tabular}{|c|c|c|c|c|c|}
\hline ORDER & JOURNAL & QUALIS & $\begin{array}{l}\text { PAPERS } \\
2013\end{array}$ & PLAGIARISM & $\begin{array}{l}\text { SELF- } \\
\text { PLAGIARISM }\end{array}$ \\
\hline 1 & BRAZILIAN ADMINISTRATION REVIEW & A2 & 12 & YES & NO \\
\hline 2 & REVISTA DE ADMINISTRAÇÃO CONTEMPORÂNEA & A2 & 18 & NO & NO \\
\hline 3 & RAP - REVISTA DE ADMINISTRAÇÃO PÚBLICA & A2 & 33 & YES & YES \\
\hline 4 & RAE - REVISTA DE ADMINISTRAÇÃO DE EMPRESAS & A2 & 19 & NO & NO \\
\hline 5 & ADMINISTRAÇÃO PÚBLICA E GESTÃO SOCIAL & B3 & 10 & YES & NO \\
\hline 6 & REVISTA DE ADMINISTRAÇÃO MACKENZIE & B1 & 25 & YES & NO \\
\hline 7 & BASE - REVISTA DE ADMINISTRAÇÃO E CONTABILIDADE DA UNISINOS & B2 & 13 & NO & YES \\
\hline 8 & ORGANIZAÇÕES \& SOCIEDADE & A2 & 8 & NO & NO \\
\hline 9 & RAU USP - REVISTA DE ADMINISTRAÇÃO & A2 & 24 & YES & YES \\
\hline 10 & BRAZILIAN BUSINESS REVIEW & A2 & 11 & YES & NO \\
\hline 11 & CADERNOS EBAPE.BR & B3 & 18 & YES & NO \\
\hline 12 & READ. REVISTA ELETROONICA DE ADMIINISTRAÇÃO & B1 & 10 & YES & NO \\
\hline 13 & DESENVOLVIMENTO EM QUESTÃO & B1 & 8 & YES & NO \\
\hline 14 & $\begin{array}{l}\text { INTERNEXT - REVISTA ELETRÔNICA DE NEGÓCIOS INTERNACIONAIS DA } \\
\text { ESPM }\end{array}$ & B5 & 5 & YES & NO \\
\hline 15 & REVISTA DE ADMINISTRAÇÃO E INOVAÇÃO & B1 & 24 & YES & NO \\
\hline 16 & REVISTA DE NEGÓCIOS & B3 & 11 & NO & NO \\
\hline 17 & REVISTA DE CIÊNCIAS DA ADMINISTRAÇÃO & B1 & 15 & YES & NO \\
\hline 18 & REVISTA ELETRÔNICA DE CIÊNCIAS ADMINISTRATIVA & B2 & 8 & NO & NO \\
\hline 19 & REVISTA GESTÃO \& TECNOLOGIA & B2 & 10 & YES & YES \\
\hline 20 & $\begin{array}{l}\text { JOURNAL OF INFORMATION SYSTEMS AND TECNOLOGY } \\
\text { MANAGEMENT }\end{array}$ & B1 & 9 & NO & NO \\
\hline 21 & REVISTA BRASILEIRA DE GESTÃO DE NEGÓCIOS & B1 & 15 & YES & YES \\
\hline 22 & CONTABILIDADE, GESTÃO E GOVERNANÇAS & B2 & 8 & YES & NO \\
\hline 23 & REVISTA DE ADMINISTRAÇÃO DA UNIMEP & B1 & 8 & YES & NO \\
\hline 24 & GESTÃO \& REGIONALIDADE & B1 & 7 & NO & NO \\
\hline 25 & REVISTA BRASILEIRA DE MARKETING & B2 & 10 & NO & NO \\
\hline 26 & REVISTA ALCANCE & B2 & 13 & NO & NO \\
\hline 27 & PENSAR CONTÁBIL & B3 & 6 & NO & NO \\
\hline 28 & REVISTA PRETEXTO & B2 & 7 & NO & NO \\
\hline 29 & REVISTA BRASILEIRA DE FINANÇAS & B1 & 10 & YES & NO \\
\hline 30 & REVISTA BRASILEIRA DE INOVAÇÃO & B2 & 8 & NO & NO \\
\hline 31 & REVISTA IBERO-AMERICANA DE ESTRATÉGIA & B2 & 10 & NO & NO \\
\hline 32 & REVISTA DE GESTÃO E PROJETOS & B3 & 9 & YES & NO \\
\hline 33 & REVISTA DA MICRO E PEQUENA EMPRESA & B3 & 7 & YES & NO \\
\hline 34 & DESAFIO ONLINE & B5 & 16 & YES & NO \\
\hline 35 & REVISTA DE GESTÃO & B2 & 16 & YES & NO \\
\hline 36 & CADERNO DE GESTÃO PÚBLICA E CIDADANIA & B3 & 4 & NO & NO \\
\hline 37 & PERSPECTIVAS EM GESTÃO \& CONHECIMENTO & B3 & 10 & YES & NO \\
\hline 38 & REVISTA DE ADMINISTRAÇÃO DA UFSM & B2 & 10 & YES & NO \\
\hline 39 & REVISTA DE GESTÃO \& PLANEJAMENTO & B2 & 10 & NO & NO \\
\hline 40 & JOURNAL OF OPERATIONS AND SUPLLY CHAIN MANAGEMENT & B3 & 8 & NO & YES \\
\hline 41 & REA - REVISTA DE ECONOMIA E ADMINISTRAÇÃO & B3 & 12 & NO & NO \\
\hline 42 & REVISTA ORGANIZAÇÕES EM CONTEXTO & B4 & 14 & YES & NO \\
\hline 43 & GESTÃO E SOCIEDADE & B3 & 6 & YES & NO \\
\hline 44 & REVISTA ELETRÔNICA DE SISTEMAS DE INFORMAÇÃO & B3 & 7 & YES & NO \\
\hline 45 & FUTURE STUDIES RESEARCH JOURNAL & B3 & 7 & YES & NO \\
\hline 46 & ORGANIZACOES RURAIS E AGROINDUSTRIAIS & B1 & 9 & YES & NO \\
\hline 47 & REVISTA ELETRONICA DE GESTAO ORGANIZACIONAL & B3 & 8 & YES & YES \\
\hline
\end{tabular}

Source: Prepared by the author using information from SPELL and from iThenticate ${ }^{\oplus}$ 
information was not encountered on these pages, analysis of the sections containing information, directives or instructions to authors followed.

It was found that on the websites of the 118 periodicals analyzed, 69 of them (58\%) have on some page or document observations and instructions related to plagiarism and self-plagiarism, which corresponds to a significant increase in relation to what was observed in the study conducted in 2013. However, it was ascertained that some journals, such as Revista de Gestão - REGE (ISSN 2177-8736), recommended that authors follow the directives of scientific integrity such as those established by COPE, though no description of those directives concerning plagiarism was offered. Other journals, such as the International Journal of Professional Business Review (e-ISSN: 2525-3654), opted for a single page concerning good conduct or policies regarding ethics in research, clearly stating the following: "Originality and Plagiarism: The authors should insure that they have written entirely original works, and if the authors have used the work and/or words of others that this has been appropriately cited or quoted. Plagiarism in all its forms constitutes unethical publishing behavior and is unacceptable." Still, other journals, such as the Revista de Administração IMED - RAIMED (ISSN 22377956), Revista de Ciências da Administração - RCA (ISSN 1516-3865) and the Revista Pensamento Contemporâneo em Administração (ISSN 1982-2596), provided a link to the document "Boas Práticas da Publicação Científica: um manual para autores, revisores, editores e integrantes de corpos editoriais" (Good Practices of Scientific Publishing: a handbook for authors, reviewers, editors and members of editorial councils) on their websites (Associação Nacional de Pesquisa e Pós-Graduação e Pesquisa em Administração (ANPAD) 2017).

To clarify the interpretation of the reports of the software used, it is important that sections of text with similarities are highlighted in color. Here, each color corresponds to a different source, and there is a superscript number in each section that permits direct access to the source with similar text. This in turn allows more precise analysis, such as the examination of whether the text comes the same author, if it was published before or after the manuscript under examination, the type of document, and other information.

From this type of analysis, by including additional documents, it is possible to affirm the occurrence of plagiarism or self-plagiarism. It is for this reason that the software detection service is offered as a verifier of similarities and not of plagiarism because not every similarity corresponds to an author's fraud. The following are three examples extracted from similarity reports generated by the iThenticate ${ }^{\circ}$ software. The examples were classified in three categories: low, medium and high incidences of plagiarism. The parameter used for each category represents the portion of paragraphs copied in relation to the manuscript.

Although there are no defined guidelines establishing the level of the seriousness of plagiarism regarding the amount reproduced, in the guidelines provided by Committee On Publication Ethics (2018) about "What to do if you suspect plagiarism", it is recommended that one consider reporting it in the following cases: "a) Unattributed use of large portions of text and/or data; b) Minor copying of short phrases only (e.g. in discussion of research paper from non-native language speaker). No misattribution of data." When large portions of text are identified, COPE recommends that editors contact the corresponding author and document the evidence of plagiarism. In the case of 
Several theoretical approaches may be useful to study the different dimensions of PPP and their impacts on costs and managerial innovations that might lead to productive efficiency in prison services. One obvious and important dimension to consider is the distribution of property rights. One of the most preminent contributions to an understanding of the public versus private dilemma. 5 , the seminal paper of Hart, Shleifer and Vishny (1997), which focuses on the comparison between public and private participation in the provision of prison services. The authors adopted an incomplete contract view, where the private operator's residual ontrol rights would reduce production costs at the expense of the quality of the services provided. In order to improve quality, the private operator must incur both the costs of quality provision and the costs of influencing the government to accept changes Q The government must agree to pay for improvements through a Nash bargaining process). Consequently, the private operators have incentives to under-provide quality and to over-reduce costs (Hart et al., 1997). Therefore, a public mode of provision is preferred when the adverse effects of cost reductions have a significant impact on quality levels or where there is limited room for quality innovations by private actors. The impact of the distribution of property rights is linked to the incompleteness of contractual agreements between the government and the private operators, which generate residual rights of control over the assets (Hat, 2003). Since it would be very difficult to contractually delineate certain tasks, such as the use of force to be employed by the private operator or the exact capabilities of the workers, Hart et al. (1997), are skeptical about privately run prisons because of the important adverse effect reduced cost strategies have on quality (i.e. under-skilled workers would lead to a higher rate of escapes).

Fig. 1 Low incidence/reviewed with QUALIS A2/2013. Source: iThenticate ${ }^{\oplus}$

a satisfactory reply addressing an honest error, unclear journal instructions or a very junior researcher, the editor can reject the manuscript or ask for a revision in the hope of obtaining improvements. Conversely, if the author's explanation is unsatisfactory, the manuscript must be rejected without the option of requesting a revision.

The first case (Fig. 1) was considered of "low incidence" because the similarities without attribution of credit appear only sporadically in some passages of the manuscript.

Figure 2 presents a case of "medium incidence" because the text reveals sections reproduced inadequately in different parts of the manuscript, but only on some pages of the entire manuscript.

The third example (Fig. 3) was considered a case of "high incidence" because it is possible to observe textual reproductions without the attribution of credit in different paragraphs on various pages, as well as differences in the provenance of the original sources copied (different colors).

A repeated observation refers to the quantity of identical terms in the same sequence of a sentence, which could indicate plagiarism. It is important to mention that the identification of patterns of similarity by software may not indicate plagiarism if the reproduced texts were correctly quoted and referenced. Therefore, it is not possible to categorically affirm that there is a predetermined amount of identical words between texts that determines plagiarism since this conclusion depends on analysis.

Some authors support the criterion of beginning a sequence with seven identical words as a parameter for judging the sequence as a verbatim copy (Saraiva and Carrieri 2009). This principle was adopted considering that "the chances of a human creating a sentence identical to another already created diminishes exponentially in relation to the number of words the sentence contains. ${ }^{4}$ "The authors demonstrated this evidence by conducting the following experiment: they used the sentence between quotation marks to search for similarity on Google (www.google.com.br) with the equivalent terms in Portuguese. The results found are presented in Table 3.

${ }^{4}$ Free translation of the following quote: "chance de um ser humano criar uma frase idêntica a outra já criada diminui exponencialmente com o número de palavras que a frase contém” 
Na opinião de Rodrigues (1999), o turismo de negócios passa a ser uma das molas propulsoras da atividade turística no século XXI e revela-se como um dos promissores segmentos do turismo, tendo o avanço das comunicações e o encurtamento das distâncias diminuído o tempo gasto nos deslocamentos e contribuído para a realização de negócios em nível nacional e global.

18

A pesquisa realizada pela Organização Mundial do Turismo $\left(C_{1}\right.$ TT, 2013) para o Anuário Estatíticico do Turismo 2013, tendo como base o ano 2012, mostra que entre os 1 tivos de viagens para o Brasil 46,8\% vieram por lazer e $25,3 \%$ por negócios, eventos e convenções. Já a demanda turística para Fortaleza, em 2013, foi de 3.141.406, sendo 2.895.646 turistas nacionais e 245.760 internacionais. Entre esses visitantes, $46,8 \%$ das motivações das viagens foram por passeio; $18,9 \%$ para visita a parentes/amigos; $20,9 \%$ para negócios/trabalho; $11,5 \%$ para congressos/eventos e 1,9\% por outros motivos (SETUR-CE, 2014). Portanto, o turismo de negócios aparece logo após o motivo de lazer, demonstrando ser representativo na cidade.

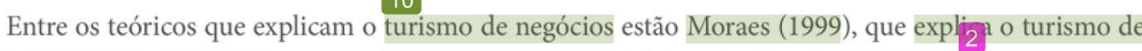
negócios como o segmento em que a motivação da viagem é determinada pelos negócios; Beni (1998), que define turismo de negócios como o deslocamento de pessoas de negócio 10 prtanto, turistas potenciais, que viajam para grandes centros cosmopolitas e empresariais, objetivando efetuar transações e atividades 15 nerciais, profissionais e industriais; e Petrocchi (2004), que acrescenta que o turismo de negócio é o conjunto de atividades de viagem, hospedagem, alimentação e de lazer praticado por quem viaja a negócios referentes a diversos setores da atividade comercial ou industrial, ou para conhecer mercados, estabelecer contatos, vender ou comprar bens e serviços.

Fig. 2 Medium incidence/reviewed with QUALIS B2/2018. Source: iThenticate ${ }^{\circledast}$

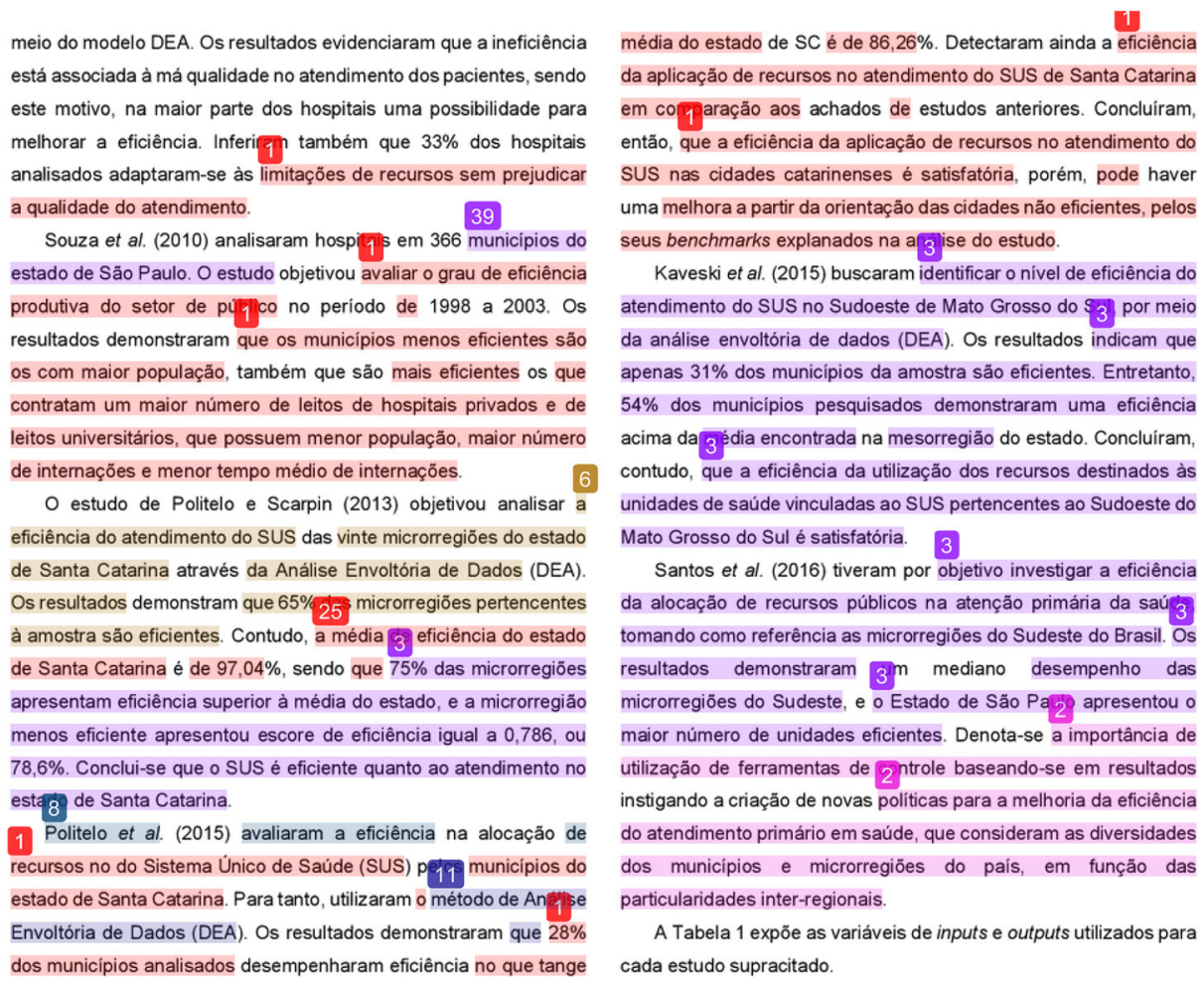

Souza et al. (2010) analisaram hospitats em 366 municipios do estado de São Paulo. O estudo objetivou avaliar o grau de eficiência produtiva do setor de púl 1 co no período de 1998 a 2003. Os resultados demonstraram que os municipios menos eficientes são os com maior população, também que são mais eficientes os que contratam um maior número de leitos de hospitais privados e de leitos universitários, que possuem menor população, maior número de internaçö̌es e menor tempo médio de internaçőes.

O estudo de Politelo e Scarpin (2013) objetivou analisar a eficiência do atendimento do SUS das vinte microrregiões do estado de Santa Catarina através da Análise Envoltória de Dados (DEA). Os resultados demonstram que $65 \% 25$ microrregiöes pertencentes à amostra são eficientes. Contudo, a média 3 eficiência do estado de Santa Catarina é de $97,04 \%$, sendo que $75 \%$ das microrregiőes apresentam eficiência superior à média do estado, e a microrregião menos eficiente apresentou escore de eficiência igual a 0,786 , ou $78,6 \%$. Conclui-se que o SUS é eficiente quanto ao atendimento no esta 8 de Santa Catarina.

1 Politelo et al. (2015) avaliaram a eficiência na alocação de recursos no do Sistema Único de Saúde (SUS) pef1 municípios do estado de Santa Catarina. Para tanto, utilizaram o método de An 1 tse Envoltória de Dados (DEA). Os resultados demonstraram que $28 \%$ dos municipios analisados desempenharam eficiência no que tange da aplicação de recursos no atendimento do SUS de Santa Catarina em co 1 araçăo aos achados de estudos anteriores. Concluiram, então, que a eficiência da aplicação de recursos no atendimento do SUS nas cidades catarinenses é satisfatória, porém, pode haver uma melhora a partir da orientaçăo das cidades não eficientes, pelos seus benchmarks explanados na a 3 lise do estudo.

Kaveski et al. (2015) buscaram identificar o nivel de eficiência do atendimento do SUS no Sudoeste de Mato Grosso do ${ }_{3}$ por meio da análise envoltória de dados (DEA). Os resultados indicam que apenas $31 \%$ dos municipios da amostra são eficientes. Entretanto, $54 \%$ dos municipios pesquisados demonstraram uma eficiência acima da 3 dia encontrada na mesorregiăo do estado. Concluiram, contudo, que a eficiência da utilização dos recursos destinados às unidades de saúde vinculadas ao SUS pertencentes ao Sudoeste do Mato Grosso do Sul é satisfatória.

Santos et al. (2016) tiveram por objetivo investigar a eficiência da alocação de recursos públicos na atenção primária da saú 3 tomando como referência as microrregiōes do Sudeste do Brasil. Os resultados demonstraram $3 \mathrm{~m}$ mediano desempenho das microrregiöes do Sudeste, e o Estado de São $\mathrm{Pa}_{2}$ apresentou o maior número de unidades eficientes. Denota-se a importância de utilização de ferramentas de $2^{\text {ntrole baseando-se em resultados }}$ instigando a criação de novas politicas para a melhoria da eficiência do atendimento primário em saúde, que consideram as diversidades dos municípios e microrregiões do pais, em função das particularidades inter-regionais.

A Tabela 1 expöe as variáveis de inputs e outputs utilizados para cada estudo supracitado. a utilização dos recursos disponiveis ao sus e que a eficiência

Fig. 3 High incidence/reviewed with QUALIS B1/2018. Source: iThenticate ${ }^{\circledR}$ 
Table 3 Parameter for judging whether a phrase is a verbatim copy

\begin{tabular}{ll}
\hline Sentence fragment & Number of pages found with the given fragment found by Google \\
\hline "A chance de um ser humano criar"a & 0 \\
"A chance de um ser humano" & 7 \\
"A chance de um ser" & 35 \\
"A chance de um" & 19,3000 \\
"A chance de" & 956,000 \\
"A chance" & $259,000,000$ \\
\hline Source: Saraiva and Carrieri (2009, p. 162) \\
aSince the search was conducted in Portuguese, the words in Portuguese were kept according to the original source. The \\
sentence refers to the first part of the quote: "the chances of a human creating..."
\end{tabular}

This experiment makes sense from the perspective of "the 'uniqueness of utterance principle', supported in linguistics, which states that when we produce a text (spoken or written) we make lexico-grammatical choices that create a sequence which is not repeated identically in other situations." (Abreu 2016, p. 5). Also, Wager (2014) have summarized some ideas regarding the extent of copy and attribution of plagiarism:

The most blatant forms of plagiarism involve the copying of entire papers or chapters which are republished as the work of the plagiarist. Such cases usually involve not only plagiarism but also breach of copyright. Whole articles or chapters may also be plagiarized in translation." (Wager 2014, p. 35) Nevertheless, these criteria cannot be considered inflexible because, first, it is acceptable to literally reproduce any quantity of text as long as the source is cited; and, second, in the specific case of plagiarism called "apt phrase," even fewer than six words can characterize plagiarism (Wager, 2014).

Nevertheless, these criteria cannot be considered inflexible because, first, it is acceptable to literally reproduce any quantity of text as long as the source is cited; and, second, in the specific case of plagiarism called "apt phrase," even two words can characterize plagiarism. That is the case of expressions created by authors to designate specific theoretical discoveries or statements in their area of research, such as the following: "I think, therefore I exist" (René Descartes), "somatic marker" (Antonio Damásio), and "knowledge conversion" (Ikugiro Nonaka \& Hirotaka Takeuchi). However, according to Committee On Publication Ethics (2009), rather than a retraction, in the case of small plagiarized parts of a text, the editor may consider, with respect to the readers and the plagiarized author, that the text be corrected.

In the analyses conducted in 2018, it was found that similarities (plagiarism and selfplagiarism) occurred in 52 articles (44\%), and there was no relevant evidence of plagiarism or self-plagiarism found in 66 (56\%) manuscripts (Table 4).

Comparing the results of the similarity reports in the two periods studied (2013 versus 2018), it is possible to confirm a reduction of $21.9 \%$ in the index of the occurrence of plagiarism and self-plagiarism. This is a relevant volume for a five-year period, although $44 \%$ is an elevated index for fraud by authors when taking into account the parameters appearing in the literature (Amos 2014). When weighing the fact that the SPELL database included a total of 28,259 articles published in the 2013-2018 period, 
Table 4 Journals indexed in the SPEL L from August 2013 to August 2018 with manuscripts containing plagiarism

\begin{tabular}{|c|c|c|c|c|c|c|}
\hline ORDER & JOURNAL & QUALIS & $\begin{array}{l}\text { PAPERS } \\
2013- \\
2018\end{array}$ & PLAGIARISM & INCIDENCE & $\begin{array}{l}\text { SELF- } \\
\text { PLAGIARISM }\end{array}$ \\
\hline 1 & $\begin{array}{l}\text { Administração: Ensino e Pesquisa - RAEP(ISSN } \\
\text { 2177-6083) }\end{array}$ & B2 & 121 & NO & & NO \\
\hline 2 & $\begin{array}{l}\text { Administração Pública e Gestão Social - APGS(ISSN } \\
\text { 2175-5787) }\end{array}$ & B1 & 146 & NO & & NO \\
\hline 3 & $\begin{array}{l}\text { Advances in Scientific and Applied Accounting - } \\
\text { ASAA(ISSN 1983-8611) }\end{array}$ & B1 & 93 & YES & $\mathrm{HIGH}$ & NO \\
\hline 4 & $\begin{array}{l}\text { Amazônia, Organizações e Sustentabilidade - } \\
\text { AOS(ISSN 2238-8893) }\end{array}$ & B3 & 89 & YES & LOW & NO \\
\hline 5 & $\begin{array}{l}\text { BASE - Revista de Administração e Contabilidade } \\
\text { da UNISINOS(ISSN 1984-8196) }\end{array}$ & B1 & 130 & NO & & NO \\
\hline 6 & $\begin{array}{l}\text { Brazilian Administration Review - BAR(ISSN 1807- } \\
\text { 7692) }\end{array}$ & $\mathrm{A} 2$ & 128 & NO & & NO \\
\hline 7 & Revista Contabilidade Gestão e Governança & B1 & 180 & YES & LOW & YES \\
\hline 8 & Brazilian Business Review - BBR(ISSN 1808-2386) & B4 & 67 & YES & $\mathrm{HIGH}$ & NO \\
\hline 9 & Cadernos EBAPE.BR - CEBAPE(ISSN 1679-3951) & A2 & 265 & NO & & NO \\
\hline 10 & $\begin{array}{l}\text { Cadernos Gestão Pública e Cidadania - CGPC(ISSN } \\
\text { 2236-5710) }\end{array}$ & B1 & 86 & NO & & NO \\
\hline 11 & Caderno Virtual de Turismo(ISSN 1677-6976) & B1 & 154 & YES & $\mathrm{HIGH}$ & NO \\
\hline 12 & $\begin{array}{l}\text { Contabilidade, Gestão e Governança - CGG(ISSN } \\
\text { 1984-3925) }\end{array}$ & B1 & 127 & NO & & NO \\
\hline 13 & $\begin{array}{l}\text { Contabilidade Vista \& Revista - CVT(ISSN 0103- } \\
\text { 734X) }\end{array}$ & $\mathrm{A} 2$ & 105 & NO & & NO \\
\hline 14 & $\begin{array}{l}\text { Contexto - Revista do Programa de Pós-Graduação } \\
\text { em Controladoria e Contabilidade da UFRGS(ISSN } \\
\text { 2175-8751) }\end{array}$ & B4 & 95 & NO & & NO \\
\hline 15 & $\begin{array}{l}\text { Contextus - Revista Contemporânea de Economia } \\
\text { e Gestão(ISSN 2178-9258) }\end{array}$ & B1 & 119 & NO & & NO \\
\hline 16 & Desafio Online(ISSN 2317-949X) & B3 & 118 & YES & LOW & NO \\
\hline 17 & Desenvolvimento em Questão(ISSN 1678-4855) & B2 & 297 & NO & & NO \\
\hline 18 & Enfoque Reflexão Contábil(ISSN 1984-882X) & B1 & 131 & NO & & NO \\
\hline 19 & $\begin{array}{l}\text { Farol - Revista de Estudos Organizacionais e } \\
\text { Sociedade(ISSN 2358-6311) }\end{array}$ & B4 & 151 & NO & & NO \\
\hline 20 & $\begin{array}{l}\text { Future Studies Research Journal: Trends and } \\
\text { Strategies }\end{array}$ & B3 & 102 & YES & LOW & NO \\
\hline 21 & Gestão \& Conexões(ISSN 2317-5087) & B4 & 3554 & YES & $\mathrm{HIGH}$ & NO \\
\hline 22 & Gestão e Sociedade - GES(ISSN 1980-5756) & B3 & 126 & YES & LOW & NO \\
\hline 23 & Gestão \& Regionalidade(ISSN 2176-5308) & B2 & 3568 & YES & $\mathrm{HIGH}$ & YES \\
\hline 24 & $\begin{array}{l}\text { GESTÃO.Org - Revista Eletrônica de Gestão } \\
\text { Organizacional }\end{array}$ & B3 & 132 & NO & & NO \\
\hline 25 & $\begin{array}{l}\text { Interface - Revista do Centro de Ciências Sociais } \\
\text { Aplicadas(ISSN 1806-9037) }\end{array}$ & B3 & 98 & YES & MEDIUM & NO \\
\hline 26 & $\begin{array}{l}\text { International Journal of Innovation - IJIISSN 2318- } \\
9975)\end{array}$ & B3 & 68 & NO & & NO \\
\hline 27 & $\begin{array}{l}\text { International Journal of Professional Business } \\
\text { Review - JPBReview(ISSN 2545-3654) }\end{array}$ & B5 & 20 & NO & & YES \\
\hline 28 & $\begin{array}{l}\text { InternexT - Revista Eletrônica de Negócios } \\
\text { Internacionais da ESPM(ISSN 1980-4865) }\end{array}$ & B3 & 87 & YES & MEDIUM & YES \\
\hline 29 & $\begin{array}{l}\text { Journal of Information Systems and Technology } \\
\text { Management - JISTEM(ISSN 1807-1775) }\end{array}$ & B1 & 140 & YES & $\mathrm{HIGH}$ & NO \\
\hline 30 & $\begin{array}{l}\text { Journal of Operations and Supply Chain } \\
\text { Management - JOSCM(ISSN 1984-3046) }\end{array}$ & B3 & 65 & NO & & NO \\
\hline 31 & Marketing \& Tourism Review(ISSN 2525-8176) & B5 & 322 & YES & MEDIUM & NO \\
\hline 32 & $\begin{array}{l}\text { NAVUS - Revista de Gestão e Tecnologia(ISSN } \\
\text { 2237-4558) }\end{array}$ & B3 & 194 & YES & LOW & $\mathrm{NO}$ \\
\hline
\end{tabular}


Table 4 Journals indexed in the SPEL L from August 2013 to August 2018 with manuscripts containing plagiarism (Continued)

\begin{tabular}{|c|c|c|c|c|c|c|}
\hline ORDER & JOURNAL & QUALIS & $\begin{array}{l}\text { PAPERS } \\
2013- \\
2018\end{array}$ & PLAGIARISM & INCIDENCE & $\begin{array}{l}\text { SELF- } \\
\text { PLAGIARISM }\end{array}$ \\
\hline 33 & $\begin{array}{l}\text { Organizações Rurais \& Agroindustriais(ISSN 1517- } \\
\text { 3879) }\end{array}$ & $\mathrm{B} 2$ & 134 & YES & LOW & NO \\
\hline 34 & Organizações \& Sociedade - O\&S(ISSN 1984-9230) & $\mathrm{A} 2$ & 657 & NO & & NO \\
\hline 35 & Pensamento \& Realidade(ISSN 2237-4418) & B3 & 354 & NO & & NO \\
\hline 36 & Pensar Contábil(ISSN 1519-0412) & B2 & 95 & YES & MEDIUM & NO \\
\hline 37 & $\begin{array}{l}\text { Perspectivas em Gestão \& Conhecimento - } \\
\text { PG\&C(ISSN 2236-417X) }\end{array}$ & B3 & 217 & NO & & NO \\
\hline 38 & $\begin{array}{l}\text { PODIUM Sport, Leisure and Tourism Review(ISSN } \\
\text { 2316-932X) }\end{array}$ & B3 & 125 & NO & & NO \\
\hline 39 & $\begin{array}{l}\text { RACE: Revista de Administração, Contabilidade e } \\
\text { Economia(ISSN 2179-4936) }\end{array}$ & B3 & 244 & NO & & NO \\
\hline 40 & $\begin{array}{l}\text { RAUnP - Revista Eletrônica do Mestrado } \\
\text { Profissional em Administração da Universidade } \\
\text { Potiguar(ISSN 1984-4204) }\end{array}$ & B3 & 77 & NO & & NO \\
\hline 41 & $\begin{array}{l}\text { REAd. Revista Eletrônica de Administração(ISSN } \\
\text { 1413-2311) }\end{array}$ & B1 & 164 & NO & & NO \\
\hline 42 & Reuna(ISSN 2179-8834) & B2 & 128 & NO & & NO \\
\hline 43 & $\begin{array}{l}\text { Reunir: Revista de Administração, Contabilidade e } \\
\text { Sustentabilidade(ISSN 2239-3667) }\end{array}$ & B2 & 126 & NO & & NO \\
\hline 44 & $\begin{array}{l}\text { Revista Acadêmica do Observatório de Inovação } \\
\text { do Turismo - OIT(ISSN 1980-6965) }\end{array}$ & B2 & 47 & NO & & NO \\
\hline 45 & $\begin{array}{l}\text { Revista Administração em Diálogo - RAD(ISSN } \\
\text { 2178-0080) }\end{array}$ & B3 & 133 & YES & $\mathrm{HIGH}$ & NO \\
\hline 46 & Revista ADM.MADE(ISSN 1518-9929) & B2 & 84 & NO & & NO \\
\hline 47 & Revista Alcance(ISSN 1983-716X) & B2 & 171 & NO & & NO \\
\hline 48 & $\begin{array}{l}\text { Revista Brasileira de Estratégia - REBRAE(ISSN 1983- } \\
\text { 8484) }\end{array}$ & B4 & 115 & NO & & NO \\
\hline 49 & $\begin{array}{l}\text { Revista Brasileira de Finanças - RBFin(ISSN 1679- } \\
\text { 0731) }\end{array}$ & B1 & 98 & YES & LOW & NO \\
\hline 50 & $\begin{array}{l}\text { Revista Brasileira de Gestão de Negócios - } \\
\text { RBGN(ISSN 1806-4892) }\end{array}$ & $\mathrm{A} 2$ & 167 & NO & & YES \\
\hline 51 & $\begin{array}{l}\text { Revista Brasileira de Gestão e Inovação(ISSN 2319- } \\
\text { 0639) }\end{array}$ & B3 & 115 & NO & & YES \\
\hline 52 & $\begin{array}{l}\text { Revista Brasileira de Inovação - RBI(ISSN 1677- } \\
\text { 2504) }\end{array}$ & B1 & 99 & NO & & NO \\
\hline 53 & $\begin{array}{l}\text { Revista Brasileira de Marketing - REMark(ISSN 2177- } \\
\text { 5184) }\end{array}$ & B2 & 223 & NO & & NO \\
\hline 54 & $\begin{array}{l}\text { Revista Brasileira de Pesquisa em Turismo - } \\
\text { RBTur(ISSN 1982-6125) }\end{array}$ & B1 & 146 & NO & & NO \\
\hline 55 & $\begin{array}{l}\text { Revista Capital Científico - Eletrônica - RCCe(ISSN } \\
\text { 1679-1991) }\end{array}$ & B3 & 171 & NO & & NO \\
\hline 56 & $\begin{array}{l}\text { Revista Catarinense da Ciência Contábil - } \\
\text { RCCC(ISSN 1808-3781) }\end{array}$ & B2 & 108 & YES & $\mathrm{HIGH}$ & NO \\
\hline 57 & $\begin{array}{l}\text { Revista Ciências Administrativas - RCA(ISSN 1414- } \\
\text { 0896) }\end{array}$ & B3 & 127 & NO & & NO \\
\hline 58 & $\begin{array}{l}\text { Revista Contabilidade \& Finanças - USP - } \\
\text { RC\&F(ISSN 1808-057X) }\end{array}$ & $\mathrm{A} 2$ & 155 & NO & & NO \\
\hline 59 & $\begin{array}{l}\text { Revista Contemporânea de Contabilidade(ISSN } \\
\text { 2175-8069) }\end{array}$ & B2 & 114 & NO & & NO \\
\hline 60 & $\begin{array}{l}\text { Revista da Micro e Pequena Empresa - RMPE(ISSN } \\
\text { 1982-2537) }\end{array}$ & B3 & 112 & NO & & NO \\
\hline 61 & Revista de Administração - RAUSP(ISSN 0080-2107) & $\mathrm{A} 2$ & 3161 & NO & & NO \\
\hline 62 & $\begin{array}{l}\text { Revista de Administração, Contabilidade e } \\
\text { Economia da FUNDACE - RACEF(ISSN 2178-7638) }\end{array}$ & B3 & 100 & NO & & NO \\
\hline 63 & Revista de Administração Contemporânea - & $\mathrm{A} 2$ & 280 & NO & & NO \\
\hline
\end{tabular}


Table 4 Journals indexed in the SPEL L from August 2013 to August 2018 with manuscripts containing plagiarism (Continued)

\begin{tabular}{|c|c|c|c|c|c|c|}
\hline ORDER & JOURNAL & QUALIS & $\begin{array}{l}\text { PAPERS } \\
2013 \text { - } \\
2018\end{array}$ & PLAGIARISM & INCIDENCE & $\begin{array}{l}\text { SELF- } \\
\text { PLAGIARISM }\end{array}$ \\
\hline & RAC(ISSN 1982-7849) & & & & & \\
\hline 64 & $\begin{array}{l}\text { Revista de Administração da UFSM - ReA } \\
\text { UFSM(ISSN 1983-4659) }\end{array}$ & B2 & 307 & YES & LOW & NO \\
\hline 65 & $\begin{array}{l}\text { Revista de Administração da Unimep - RAU(ISSN } \\
\text { 1679-5350) }\end{array}$ & B2 & 141 & YES & $\mathrm{HIGH}$ & NO \\
\hline 66 & $\begin{array}{l}\text { Revista de Administração de Empresas - RAE(ISSN } \\
\text { 0034-7590) }\end{array}$ & A2 & 342 & NO & & NO \\
\hline 67 & $\begin{array}{l}\text { Revista de Administração e Inovação - RAI(ISSN } \\
\text { 1809-2039) }\end{array}$ & B1 & 223 & NO & & NO \\
\hline 68 & $\begin{array}{l}\text { Revista de Administração FACES Journal - } \\
\text { FACES(ISSN 1984-6975) }\end{array}$ & B2 & 152 & NO & & NO \\
\hline 69 & $\begin{array}{l}\text { Revista de Administração Hospitalar e Inovação } \\
\text { em Saúde - RAHIS(ISSN 1983-5205) }\end{array}$ & B3 & 140 & YES & $\mathrm{HIGH}$ & NO \\
\hline 70 & $\begin{array}{l}\text { Revista de Administração IMED - RAIMED(ISSN } \\
\text { 2237-7956) }\end{array}$ & B3 & 118 & NO & & NO \\
\hline 71 & $\begin{array}{l}\text { Revista de Administração Mackenzie - RAM(ISSN } \\
\text { 1678-6971) }\end{array}$ & B1 & 264 & NO & & NO \\
\hline 72 & $\begin{array}{l}\text { Revista de Administração Pública - RAP(ISSN 0034- } \\
\text { 7612) }\end{array}$ & A2 & 318 & NO & & NO \\
\hline 73 & $\begin{array}{l}\text { Revista de Administração, Sociedade e Inovação - } \\
\text { RASI(ISSN 2447-8156) }\end{array}$ & B3 & 40 & YES & $\mathrm{HIGH}$ & NO \\
\hline 74 & $\begin{array}{l}\text { Revista de Carreiras e Pessoas - RECAPE(ISSN 2237- } \\
\text { 1427) }\end{array}$ & B4 & 129 & NO & & NO \\
\hline 75 & $\begin{array}{l}\text { Revista de Ciências da Administração - RCA(ISSN } \\
\text { 1516-3865) }\end{array}$ & B1 & 165 & NO & & NO \\
\hline 76 & $\begin{array}{l}\text { Revista de Contabilidade do Mestrado em Ciências } \\
\text { Contábeis da UERJ(ISSN 1984-3291) }\end{array}$ & B1 & 80 & NO & & YES \\
\hline 77 & $\begin{array}{l}\text { Revista de Contabilidade e Organizações - } \\
\text { RCO(ISSN 1982-6486) }\end{array}$ & $\mathrm{A} 2$ & 85 & NO & & YES \\
\hline 78 & $\begin{array}{l}\text { Revista de Economia e Administração - REA(ISSN } \\
\text { 1676-6760) }\end{array}$ & & 27 & NO & & NO \\
\hline 79 & $\begin{array}{l}\text { Revista de Educação e Pesquisa em Contabilidade } \\
\text { - REPeC(ISSN 1981-8610) }\end{array}$ & B1 & 143 & NO & & NO \\
\hline 80 & $\begin{array}{l}\text { Revista de Empreendedorismo e Gestão de } \\
\text { Pequenas Empresas - REGEPE(ISSN 2316-2058) }\end{array}$ & B1 & 119 & YES & MEDIUM & YES \\
\hline 81 & $\begin{array}{l}\text { Revista de Finanças Aplicadas - RFA(ISSN 2176- } \\
\text { 8854) }\end{array}$ & B3 & 52 & YES & LOW & NO \\
\hline 82 & $\begin{array}{l}\text { Revista de Gestão e Secretariado - REGE(ISSN } \\
\text { 2177-8736) }\end{array}$ & B1 & 1122 & YES & LOW & NO \\
\hline 83 & $\begin{array}{l}\text { Revista de Gestão Ambiental e Sustentabilidade - } \\
\text { GEAS(ISSN 2316-9834) }\end{array}$ & B3 & 146 & YES & MEDIUM & NO \\
\hline 84 & $\begin{array}{l}\text { Revista de Gestão em Sistemas de Saúde - } \\
\text { RGSS(ISSN 2316-3712) }\end{array}$ & B3 & 97 & NO & & NO \\
\hline 85 & $\begin{array}{l}\text { Revista de Gestão e Projetos - GeP(ISSN 2236- } \\
\text { 0972) }\end{array}$ & B3 & 105 & NO & & NO \\
\hline 86 & $\begin{array}{l}\text { Revista de Gestão e Secretariado - Gesec(ISSN } \\
\text { 2178-9010) }\end{array}$ & B2 & 143 & YES & MEDIUM & NO \\
\hline 87 & $\begin{array}{l}\text { Revista de Gestão, Finanças e Contabilidade(ISSN } \\
\text { 2238-5320) }\end{array}$ & B2 & 164 & NO & & NO \\
\hline 88 & $\begin{array}{l}\text { Revista de Gestão Social e Ambiental - RGSA(ISSN } \\
\text { 1981-982X) }\end{array}$ & B1 & 107 & YES & LOW & NO \\
\hline 89 & Revista de Negócios(ISSN 1980-4431) & B2 & 80 & YES & $\mathrm{HIGH}$ & NO \\
\hline 90 & $\begin{array}{l}\text { Revista de Tecnologia Aplicada - RTA(ISSN 2237- } \\
\text { 3713) }\end{array}$ & B3 & 69 & NO & & NO \\
\hline 91 & Revista do Serviço Público - RSP(ISSN 2357-8017) & B4 & 160 & NO & & NO \\
\hline 92 & Revista Economia \& Gestão - E\&G(ISSN 1984-6606) & B2 & 158 & YES & $\mathrm{HIGH}$ & NO \\
\hline
\end{tabular}


Table 4 Journals indexed in the SPEL L from August 2013 to August 2018 with manuscripts containing plagiarism (Continued)

\begin{tabular}{|c|c|c|c|c|c|c|}
\hline ORDER & JOURNAL & QUALIS & $\begin{array}{l}\text { PAPERS } \\
2013- \\
2018\end{array}$ & PLAGIARISM & INCIDENCE & $\begin{array}{l}\text { SELF- } \\
\text { PLAGIARISM }\end{array}$ \\
\hline$\overline{93}$ & $\begin{array}{l}\text { Revista Eletrônica Científica do CRA-PR - } \\
\text { RECC(ISSN 2358-7083) }\end{array}$ & B3 & 55 & YES & $\mathrm{HIGH}$ & YES \\
\hline 94 & $\begin{array}{l}\text { Revista Eletrônica de Ciência Administrativa - } \\
\text { RECADM(ISSN 1677-7387) }\end{array}$ & B1 & 94 & NO & & YES \\
\hline 95 & $\begin{array}{l}\text { Revista Eletrônica de Estratégia \& Negócios - } \\
\text { REEN(ISSN 1984-3372) }\end{array}$ & B2 & 152 & NO & & NO \\
\hline 96 & $\begin{array}{l}\text { Revista Eletrônica de Sistemas de Informação - } \\
\text { RESI(ISSN 1677-3071) }\end{array}$ & B3 & 57 & NO & & NO \\
\hline 97 & $\begin{array}{l}\text { Revista Eletrônica Gestão e Serviços - REGS(ISSN } \\
\text { 2177-7284) }\end{array}$ & B3 & 82 & NO & & NO \\
\hline 98 & $\begin{array}{l}\text { Revista Evidenciação Contábil \& Finanças - } \\
\text { RECFin(ISSN 2318-1001) }\end{array}$ & B3 & 119 & NO & & NO \\
\hline 99 & $\begin{array}{l}\text { Revista Gestão Organizacional - RGO(ISSN 1983- } \\
\text { 6635) }\end{array}$ & B4 & 88 & NO & & YES \\
\hline 100 & $\begin{array}{l}\text { Revista Gestão \& Planejamento - G\&P(ISSN 2178- } \\
\text { 8030) }\end{array}$ & B2 & 424 & NO & & NO \\
\hline 101 & Revista Gestão \& Tecnologia(ISSN 1677-9479) & B3 & 238 & YES & $\mathrm{HIGH}$ & NO \\
\hline 102 & Revista Gestão \& Tecnologia ISSN 2177-6652 & B3 & 458 & NO & & NO \\
\hline 103 & Revista Hospitalidade(ISSN 2179-9164) & B2 & 114 & NO & & NO \\
\hline 104 & $\begin{array}{l}\text { Revista Ibero-Americana de Estratégia - RIAE(ISSN } \\
2176-0756)\end{array}$ & B2 & 189 & NO & & NO \\
\hline 105 & $\begin{array}{l}\text { Revista Interdisciplinar de Gestão Social - } \\
\text { RIGS(ISSN 2317-2428) }\end{array}$ & B4 & 144 & YES & $\mathrm{HIGH}$ & YES \\
\hline 106 & $\begin{array}{l}\text { Revista Interdisciplinar de Marketing - RIMAR(ISSN } \\
\text { 1676-9783) }\end{array}$ & B4 & 63 & NO & & YES \\
\hline 107 & $\begin{array}{l}\text { Revista Mineira de Contabilidade - RMC(ISSN 2446- } \\
\text { 9114) }\end{array}$ & B3 & 99 & YES & MEDIUM & NO \\
\hline 108 & $\begin{array}{l}\text { Revista Organizações em Contexto - ROC(ISSN } \\
\text { 1982-8756) }\end{array}$ & B1 & 173 & NO & & NO \\
\hline 109 & $\begin{array}{l}\text { Revista Pensamento Contemporâneo em } \\
\text { Administração(ISSN 1982-2596) }\end{array}$ & B2 & 217 & YES & $\mathrm{HIGH}$ & NO \\
\hline 110 & Revista Pretexto(ISSN 1517-672X) & B3 & 160 & YES & LOW & NO \\
\hline 111 & Revista Universo Contábil - RUC(ISSN 1809-3337 & $\mathrm{A} 2$ & 163 & NO & & YES \\
\hline 112 & $\begin{array}{l}\text { Rosa dos Ventos - Turismo e Hospitalidade(ISSN } \\
\text { 2178-9061) }\end{array}$ & B2 & 218 & YES & $\mathrm{HIGH}$ & NO \\
\hline 113 & $\begin{array}{l}\text { SINERGIA - Revista do Instituto de Ciências } \\
\text { Econômicas, Administrativas e Contábeis (ICEAC) }\end{array}$ & B4 & 72 & YES & $\mathrm{HIGH}$ & NO \\
\hline 114 & $\begin{array}{l}\text { Sociedade, Contabilidade e Gestão(ISSN } 1982- \\
\text { 7342) }\end{array}$ & B2 & 113 & NO & & YES \\
\hline 115 & $\begin{array}{l}\text { Tecnologias de Administração e Contabilidade - } \\
\text { TAC(ISSN 2236-0263) }\end{array}$ & & 38 & NO & & NO \\
\hline 116 & $\begin{array}{l}\text { Teoria e Prática em Administração - TPA(ISSN } \\
\text { 2238-104X) }\end{array}$ & B2 & 104 & YES & MEDIUM & NO \\
\hline 117 & Turismo em Análise - RTA(ISSN 1984-4867) & B1 & 161 & NO & & NO \\
\hline 118 & Turismo: Visão e Ação - RTVA(ISSN 1415-6393) & B1 & 143 & YES & LOW & NO \\
\hline
\end{tabular}

Source: Prepared by the author with information from SPELL and from iThenticate ${ }^{\oplus}$

the percentage of observed fraud by authors was $0.18 \%$, which represents a highly noteworthy number compared to the study conducted by Amos (2014). From a sample of $0.02 \%$ of the retracted articles in the PubMed database in the period from 2008 to 2012, that study deemed 35\% included plagiarism or self-plagiarism.

Notably, 16 articles (14\%) were determined to have evidence of self-plagiarism, or rather they were manuscripts that had been published in the form of theses. They were 
indexed in open-access repositories, had been presented at scientific events and appeared in their proceedings, or even were published in other journals. Self-plagiarism, or redundancy, is considered a fraudulent practice in the international and Brazilian contexts. COPE warns that published articles should be retracted if, among other reasons, "they have clear evidence that the findings are unreliable, either as a result of misconduct (e.g., data fabrication) or honest error (e.g. miscalculation or experimental error); the findings have previously been published elsewhere without proper cross-referencing, permission or justification (i.e. cases of redundant publication); it constitutes plagiarism; it reports unethical research" (Committee On Publication Ethics 2009).

Still, it is necessary to recognize that there is a certain degree of controversy related to self-plagiarism. First, definitions concerning the undue appropriation of published works refer to the presentation as one's own of someone else's work. Therefore, considering the copying of one's own work (self-plagiarism) as fraud cannot be accepted either conceptually or juridically. Regarding the system for attributing scientific credibility that considers the number of publications as a form of ascertaining scientific productivity, it might make sense to characterize selfplagiarism as redundancy. Thus, decreasing self-reproduction can be a way of preventing a single work from being presented as several works, giving a false notion of productivity.

It is fitting to discuss at what point plagiarism is considered a problem by editors and researchers because if it is not a concern, then its absence in the mechanisms of control and punishment is not warranted. Nevertheless, the directives of COPE for editors clearly recommend that mechanisms for the detection of plagiarism be adopted and that reviewers be supported and encouraged to verify the occurrence of plagiarism (Committee On Publication Ethics 2011).

Although the occurrence of plagiarism and self-plagiarism is not well known, it can be questioned whether the absence of editorial guidelines concerning these issues in the policy directives given to authors influences the numerical results. The fact that observation reveals that only one periodical sets forth specific directives concerning plagiarism appears to suggest that this problem apparently does not concern editors in relation to the requirements that must be met by authors. Nevertheless, plagiarism is a problem that exists in the academic world, and its occurrence has been measured among researchers in different fields and countries, with clear indications that its frequency is increasing.

COPE itself offers two flowcharts showing possible actions when plagiarism is suspected in manuscripts and in articles already published to help editors. These guidelines vary depending on the seriousness of the plagiarism, the degree of intentionality, and the extent of the responsibility of the author because there are works that contain a few sentences or many segments of literally and improperly reproduced material, cases in which the sources used were not correctly identified due to the researcher's technical failure, and differences between the plagiarism occurring in a manuscript by a novice researcher and that of a senior investigator.

It is well known that the objective of research work is to contribute to human development; therefore, the greater the visibility a scientific discovery has, the greater the number of people that are able to obtain the resulting benefits. Thus, it is possible to note in the publication directives that it is considered acceptable to publish work previously presented at conferences or divulged in repositories. 


\section{Conclusion}

The results obtained in this study contribute to the understanding of plagiarism in the context of scientific publications in the area of business in Brazil. Although a reduction in the indices of the occurrence of plagiarism was observed in published articles, as was an increase in the support regarding the prevention of plagiarism by authors in the editorial requirements of periodicals, evidence of the problem continues to remain a concern due to it impact on the reputations of researchers and journals. Nevertheless, it is possible to argue that these indices result from bad faith on the part of researchers less than might be thought. Indeed, it is often found that plagiarism can occur accidentally due to technical difficulties or ignorance of the practices involved in attributing sources. This thinking supports the idea that no scientist should risk having his name and reputation exposed publicly due to a manuscript with fraudulent textual segments since it is currently extremely easy to determine textual similarity using specialized software. Hence, the verification of such occurrences generally reveals carelessness, a lack of concern, or unpreparedness in relation to the matter. Similarly, just as it is not a question of simply attributing the responsibility of plagiarism to the researcher, one must consider the portion of responsibility of others involved in the process of the production and publication of scientific knowledge, such as the editors and the financing agencies.

Consequently, it can be recommended that the editors of the periodicals studied adopt practices directed at informing authors of the importance of preventing plagiarism in the manuscripts submitted for publication via directives. In addition, this action has been recommended by diverse institutions related to scientific production and should be increased by augmenting the capacity of reviewers such that they evaluate the articles submitted for publication, verify the occurrence of plagiarism, and adopt the use of plagiarism detection software as a standard procedure for periodicals. In this way, many works that are published today and are accused of plagiarism can be identified in the submission process, and their authors can be advised to make appropriate preventive corrections.

In conclusion, plagiarism is a problem that must be considered not from the perspective of finding culprits, but rather as a challenge to be overcome that requires collective and committed work on the part of all those involved in the research process, including researchers, editors, research institutions, and financing agencies, among others. However, the first and most fundamental step is the recognition that the problem exists and requires a response and a position from all those involved. This was clearly demonstrated in the present study.

It is recommended that similar studies be conducted using other databases with indices or other types of scientific publications and in different areas of study. It is additionally recommended that the results of these studies be compared with those of similar studies conducted in other contexts, always with the essential objective of contributing to the improvement of the actions for combating plagiarism and consequently strengthening the credibility of science in Brazil and other countries. 
Editors; FAPESP: Foundation for the Support to Research of the State of São Paulo; OAB: Brazilian Bar Association; SPEL L: Scientific Periodicals Electronic Library; USP: São Paulo University

\section{Acknowledgements}

I would like to express my sincere gratitude to Prof. Fredric Michael Litto with who I am having the opportunity to share ideas and reflections on plagiarism and academic integrity. I am also grateful for his contribution translating this manuscript to English. I would like also to say thank you to Talita Fonseca, for her support collecting data.

Code availability

Not applicable.

\section{Author's contributions}

The research was done by a single author. Collaborators were thanked in the corresponding section. The author(s) read and approved the final manuscript.

\section{Funding}

This research did not receive any external funding. Fundação Escola de Comércio Álvares Penteado (FECAP) provided funding for openly publishing the manuscript.

\section{Availability of data and materials}

The data and materials are not available to readers because they are sensitive content that may embarrass the authors of the manuscripts in which plagiarism and or self-plagiarism were found. However, they can be made available for controlled access by editors and reviewers. Despite the unavailability of data and materials from the selected sample, the reproducibility of the study results can be performed because access to the material is open-access in the Scientific Periodicals Electronic Library (SPELL).

\section{Competing interests}

Although the data analysis was developed using the iThenticate ${ }^{\oplus}$, a commercial software to detect similarities in the text, the author declare that he has no conflict of interest.

Received: 25 May 2020 Accepted: 9 November 2020

Published online: 07 January 2021

\section{References}

Abreu, BB (2016) Investigating plagiarism in the academic context. 2016. 220 f. Tese (Doutorado) - Curso de Programa de Pós-Graduação em Inglês, Estudos Linguísticos e Literários, Universidade Federal de Santa Catarina, Florianopolis

Alves, G (2017) Fapesp bloqueará verba de instituição que não adotar medidas antiplágio. Jornal Folha de São Paulo. Retrieved from https://www1.folha.uol.com.br/ciencia/2017/04/1878564-fapesp-bloqueara-verba-de-instituicao-que-naoadotar-medidas-antiplagio.shtml?origin=folha. Accessed 04 Oct 2020

Amos KA (2014) The ethics of scholarly publishing: exploring differences in plagiarism and duplicate publication across nations. J Med Libr Assoc 102(2):87-91

Andrade JX (2011) Má conduta na pesquisa em ciências contábeis. 2011, p 125 Tese (Doutorado em Ciências Contábeis Universidade de São Paulo

Associação Nacional de Pesquisa e Pós-Graduação e Pesquisa em Administração (ANPAD) (2017) Boas Práticas da Publicação Científica: um manual para autores, revisores, editores e integrantes de corpos editoriais 2017. Retrieved from http:// www.anpad.org.br/ anpad/diversos/2017/2017_Boas_Praticas.pdf. Accessed 04 Jul 2019

Australian Government (2007) Australian code for the responsible conduct of research 2007. Retrieved from https:/www. nhmrc.gov.au/about-us/publications/australian-code-responsible-conduct-research-2007. Accessed 05 Jul 2019

Badge, J, Scott, J (2009) Dealing with plagiarism in the digital age What is electronic detection of plagiarism? Retrieved from http://evidencenet.pbworks.com/w/page/19383480/Dealing\%20with\%20plagiarism\%20in\%20the\%20digital\%20age. Accessed 5 Jul 2019

Barbastefano, RG \& Souza, CG (2007) Percepção do conceito de plágio acadêmico entre alunos de engenharia de produção e ações para sua redução. Revista Produção Online, Florianópolis, 7 (4)

Barros, TD \& Duque, APO (2015) O cenário do plágio acadêmico sob a ótica informacional de pesquisadores brasileiros na BDTD e no ENANPAD. In: CONVIBRA 2015, Rio de Janeiro. Anais... Rio de Janeiro. Retrieved from http://www.convibra. com.br/upload/paper/2015/31/2015_31_11898.pdf. Accessed 06 Jul 2019

Biondi, A (2011) Plágio na produção acadêmica, vespeiro intocado. Ou não? Revista Adusp, São Paulo, 50 (90)

Bird SB, Sivilotti MLA (2008) Self-plagiarism, recycling fraud, and the intent to mislead. J Med Toxicol 4:69

Brasil (2016) Ministério Da Educação. Plataforma sucupira: Qualis. Retrieved from https://sucupira.capes.gov.br/sucupira/ public/index.jsfijsessionid=tVIr+CEzblCSaOT2Is0tR+yd.sucupira-205\#. Accessed 03 Oct 2020

Carver JD et al (2011) Ethical considerations in scientific writing. Indian J Sex transm Dis 32(2):124-128

Committee On Publication Ethics (2009). Retractions: Guidance from the Committee on Publication Ethics. Retrieved from https://publicationethics.org/files/u661/Retractions_COPE_gline_final_3_Sept_09__2_pdf. Accessed 05 Jul 2019

Committee On Publication Ethics (2011) Code of conduct and best practice guidelines for jornal editors. Retrieved from http://publicationethics.org/files/Code_of_conduct_for_journal_editors_Mar11.pdf. Accessed 05 Jul 2019

Committee On Publication Ethics (2016) What to do if you suspect redundant (duplicate) publication (b) Suspected redundant publication in a published manuscript. Retrieved from https://publicationethics.org/files/redundant\%2 Opublication\%20A_0.pdf. Accessed 05 Jul2019

Committee On Publication Ethics (2018) What to do if you suspect plagiarism (a) Suspected plagiarism in a submitted manuscript. Retrieved from https://publicationethics.org/files/plagiarism\%20A.pdf. Accessed $05 \mathrm{Jul} 2019$ 
Concordia University (2019) What is Plagiarism. Retrieved from https://www.concordia.ca/students/academic-integrity/ plagiarism.html. Accessed 05 Jul 2019

Conselho Nacional de Desenvolvimento Científico Tecnológico (2011) Relatório da Comissão de Integridade de Pesquisa do CNPq. Retrieved from http://www.cnpq.br/documents/10157/a8927840-2b8f-43b9-8962-5a2ccfa74dda. Accessed 07 Jul 2019

Coordenação de Aperfeiçoamento de Pessoal de Nível Superior (2009) What are CAPES's main activities. Retrieved from http://www.periodicos.capes.gov.br/?option=com_pnews\&component=Clipping\&view=pnewsclipping\&cid=57\&mn=0. Accessed 19 October 2020

Coordenação de Aperfeiçoamento de Pessoal de Nível Superior (2011). Orientações Capes: combate ao plágio. Retrieved from http://www.capes.gov.br/images/stories/download/diversos/OrientacoesCapes_CombateAoPlagio.pdf. Accessed 05 Jul 2019

Costa FJ, Socorro CTS, Muzzio H (2017) Uma Reflexão sobre Autoria Acadêmica. Teoria e Prática em Administração 7(1):1-25

Council of Science Editors (2018) CSE's White Paper on Promoting Integrity in Scientific Journal Publications. Retrieved from https://www.councilscienceeditors.org/wp-content/uploads/CSE-White-Paper_2018-update-050618.pdf. Accessed 06 Jul 2019

Demo P (2011) Remix, pastiche, plágio: autorias da nova geração. Meta: Avaliação 3(8):125-144

Eaton SE, Crossman K (2018) Self-plagiarism research literature in the social sciences: a scoping review. Interchange 49:285311. https://doi.org/10.1007/s10780-018-9333-6

Cadernos Ebape (2014). Diretrizes para autores. Retrieved from http://bibliotecadigital.fgv.br/ojs/index.php/cadernosebape/ pages/view/normas. Accessed 15 Jan 2014

Fachini GJ, Domingues MJCS (2008) Percepção do plágio acadêmico entre alunos de programas de pós-graduação em administração e contabilidade. Anais dos Seminários em Administração São Paulo, SP, Brasil, XI

Ferreira ABH (1986) Novo dicionário da Língua Portuguesa, 2nd edn. Nova Fronteira, Rio de Janeiro

Fundação de Amparo à Pesquisa do Estado de São Paulo (2011) Código de boas práticas científicas. Retrieved from http:// www.fapesp.br/boaspraticas/codigo_050911.pdf. Accessed 05 Jul 2019

Fundação de Amparo à Pesquisa do Estado de São Paulo (2014). Sumário de casos. Retrieved from https://fapesp.br/8577/ sumarios-de-casos. Accessed 04 Oct 2020

Garcia, GR (2013) Fraude y plagio academic en los ambientes virtuales de aprendizaje 2013. Retrieved from https://portafolis. urv.cat/artefact/file/download.php?file=12835\&view=3272. Accessed 05 Jul 2019

Georgetown University (2019) Examples of Plagiarism. Retrieved from https://honorcouncil.georgetown.edu/system/what-isplagiarism/x. Accessed 05 Jul 2019

Harris R (2001) The plagiarism handbook. Pyrczak Publishing, Los Angeles

Innarelli, PB (2011) Fatores antecedentes na atitude de alunos de graduação frente ao plágio. (Dissertação de Mestrado). Universidade Metodista de São Paulo, São Bernardo do Campo, SP, Brasil

IThenticate ${ }^{\oplus}$ (2019) Prevent Plagiarism in Published Works. Retrieved from http://www.ithenticate.com/. Accessed 04 Jul 2019

Job I, Mattos AM, Trindade A (2009) Processo de revisão pelos pares: por que são rejeitados os manuscritos submetidos a um periódico científico. Movimento, Porto Alegre 15(3): 1-17.

Koocher GP, Keith-Spiegel P (2010) Peers nip misconduct in the bud. Nature 466(7305):438-440

Krokoscz M (2011) Abordagem do plágio nas três melhores universidades de cada um dos cinco continentes e do Brasil. Rev Brasileira de Educação 16(48):745-818

Krokoscz M (2012a) A literature review of scientific research and reflections on plagiarism in Brazil since 1990. In 5th International Plagiarism Conference 16-18 July, Newcastle UK.

Krokoscz M (2012b) Autoria e Plágio: um guia para estudantes, professores, pesquisadores e editores. Atlas, São Paulo

Loui MC (2002) Seven ways to plagiarise. Sci Eng Ethics 8(4):529-539.

Martin B (1994) Plagiarism: a misplaced emphasis. J Inf Ethics 3(2):36-47

Masic I (2014) Plagiarism in scientific research and publications and how to prevent it. Materia Socio Medica 26(2):141

Massachusetts Institute Of Technology (2018) Academic Integrity: Incorporating the Words and Ideas of Others. Retrieved from http://integrity.mit.edu/sites/default/files/documents/AcademiclntegrityHandbook2018-color.pdf. Accessed 05 Jul 2019

Neumann, E (2018) Relação entre os fatores antecedentes e a atitude de plágio em estudantes de administração. (Dissertação de Mestrado). Universidade Regional de Blumenau, Blumenau, SC, Brasil

OAB (2010) Combate ao Plágio - Comissão Nacional de Relações Institucionais do Conselho Federal da OAB. Retrieved from http://www2.ib.usp.br/files/doc_\%20plagio_OAB.pdf. Accessed 04 Oct 2020

Research Councils UK (2017) RCUK Policy and Code of Conduct on the Governance of Good research Conduct. Retrieved from https://www.ukri.org/files/legacy/reviews/grc/rcuk-grp-policy-and-guidelines-updated-apr-17-2-pdf/. Accessed 5 Jul 2019.

Retraction Watch (2019) The Retraction Watch Database. Version 1.0.5.5. 2019. Retrieved from http://retractiondatabase.org/ RetractionSearch.aspx. Accessed 04 Jul 2019

Revista Brasileira de Marketing (2014) Diretrizes para autores. Retrieved from http://www.revistabrasileiramarketing.org/ ojs-2.2.4/index.php/remark/about/submissions\#onlineSubmissions. Accessed 16 Jan 2014

Revista de Administração e Contabilidade da Unisinos (2014) Diretrizes para autores. Retrieved from http://revistas.unisinos.br/ index.php/base/about/submissions\#onlineSubmissions. Accessed 14 Jan 2014

Revista de Gestão, Finanças e Contabilidade (2014) Diretrizes para autores. Retrieved from https://www.revistas.uneb.br/index. php/financ/about/submissions\#authorGuidelines. Accessed 14 Jan 2014

Roig, M (2015) Avoiding plagiarism, self-plagiarism, and other questionable writing practices: a guide to ethical writing. Retrieved from https://ori.hhs.gov/sites/default/files/plagiarism.pdf . Accessed 28 Sep 2012

Samuelson P (1994) Self-plagiarism or fair use? Commun ACM 37(8):21-25

Saraiva EV, Carrieri AP (2009) Citações e não citações na produção acadêmica de estratégia no Brasil: uma reflexão crítica. Rev de Administração - RAUSP 44(2):158-166

Silva AKL, Domingues MJCS (2008) Plágio no meio acadêmico: de que forma alunos de pós-graduação compreendem o tema. Perspect Contemp 3(2):117-135 
Stanford University (2019) Sample plagiarism. Retrieved from https://communitystandards.stanford.edu/policies-andguidance/what-plagiarism/sample-plagiarism-cases. Accessed 05 Jul 2019

The University of Hong Kong (2019) What is plagiarism. Retrieved from http://www.rss.hku.hk/plagiarism/page2s.htm. Accessed 05 Jul 2019

Tomazelli, KG (2011) Desonestidade acadêmica e profissional: avaliação das percepções de estudantes de Administração e Contabilidade. (Trabalho de conclusão de curso). Universidade Federal do Rio Grande do Sul, Porto Alegre, RS, Brasil

U.S. Department Of Health And Human Services (2005) Public health service policies on research misconduct. Final rule. Federal register 70(94):28369-28400

Universiteit Ghent (2019) Education and Examination Code Academic Year 2019-2020. Retrieved from https://www.ugent.be/ student/en/class-exam-exchange-intern/class-exam/education-examination-code/oeren20192020.pdf/at_download/file. Accessed 20 Apr 2013

University of Cambridge (2019a) University-wide statement on plagiarism. Retrieved from http://www.admin.cam.ac.uk/univ/ plagiarism/students/statement.html. Accessed 05 Jul 2019

University of Cambridge (2019b) Collusion. Retrieved from https://www.plagiarism.admin.cam.ac.uk/what-plagiarism/collusion. Accessed 05 Jul 2019

University of Cape Town (2019) Avoiding plagiarism: a guide for students. Retrieved from https://www.uct.ac.za/sites/default/ files/image_tool/images/328/about/policies/Guide_StudentGuideOnAvoidingPlagiarism.pdf. Accessed: 05 Jul 2019

University of Oxford (2019) What is plagiarism. Retrieved from http://www.ox.ac.uk/students/academic/goodpractice/about/. Accessed 05 Jul 2019

University of Pretoria (2019) What is plagiarism. Retrieved from https://www.up.ac.za/students/article/2745913/what-is plagiarism. Accessed 20 Apr 2013

Valente, NTZ et al. (2010) Reasons that lead undergraduate students in the business administration course to misuse ready papers taken from the internet. Anais do CONTECSI - International Conference on Information Systems and Technology Management, 7. São Paulo, SP, Brasil

Van Noorden R (2011) Science publishing: the trouble with retractions. Nature 478:26-28.

Veludo-De-Oliveira TM et al (2014) Cola, plágio. Ram, Rev Adm. Mackenzie 15(1):73-97

WAGER, E (2014) Defining and responding to plagiarism. Learned Publishing, 27 (1): 33-42.

\section{Publisher's Note}

Springer Nature remains neutral with regard to jurisdictional claims in published maps and institutional affiliations.

Ready to submit your research? Choose BMC and benefit from:

- fast, convenient online submission

- thorough peer review by experienced researchers in your field

- rapid publication on acceptance

- support for research data, including large and complex data types

- gold Open Access which fosters wider collaboration and increased citations

- maximum visibility for your research: over $100 \mathrm{M}$ website views per year

At $B M C$, research is always in progress.

Learn more biomedcentral.com/submissions 